\title{
The End of Universal Jurisdiction in Spain?
}

\author{
Montserrat ABAD CASTELOS*
}

\section{DID INTERNATIONAL LAW REQUIRE A MODIFICATION OF THE EXISTING MODEL AS THE PREAMBLE OF THE NEW ACT SUGGESTS?}

The starting point is the fact that the principle of universal jurisdiction, unlike all other criminal law principles, is not linked to any of the traditional elements of statehood, but only to the extremely serious nature of the crime, affecting core values of the international community. Therefore, offences of this nature are considered to be directed against the international community as a whole, as well as against every State.

International law did indeed require a modification of the previously existing model, but in the opposite sense to the effectively carried out in 20I4. It would have been necessary then to recover the principle of universal jurisdiction's true essence, since the reform made by the 2009 Act, modifying its previous content (first established in 1985), had introduced new elements that were completely unrelated to it (such as the requirement or "victims [to be] of Spanish nationality" or "a relevant link with Spain") and introduced an unfounded subsidiarity factor (with respect to the existence of another [judicial?] process in other countries). That normative framework presented these and other deficiencies, which have already been correctly analysed by experts, whose conclusions we support ${ }^{2}$. Although the 2009 Act had left the door partly open to circumvent those constraints (providing that the Spanish courts' jurisdiction on such crimes would be subject to the accreditation of the new requirements, "without prejudice to the provisions of the treaties and international agreements ratified by Spain"), its scope was totally insufficient.

The recent 2014 Act has thus introduced a new reform contrary to the one needed. Far from solving these problems, it has, by trying to further restrict the scope of universal jurisdiction in Spain, in fact, emptied and denaturalized its content, adding new difficulties. Consequently, Spanish

Professor of Public International Law, University Carlos III of Madrid. Mabad@der-pu.uczm.es.

A. Sánchez Legido, A., Jurisdicción universal penal y Derecho internacional (Tirant lo Blanch, Valencia, 2004) at. 37.

See J. Chinchón Álvarez, J., "A propósito del proceso de reforma del artículo 23.4 de la Ley Orgánica del Poder Judicial (mayo-noviembre de 2009): De los motivos a las consecuencias para el principio de jurisdicción universal”, 6 Revista de Derecho de Extremadura(2009), pp. I3-3I; id., "Análisis formal y material de la reforma del principio de jurisdicción universal en la legislación española: De la 'abrogación de facto' a la 'derogación de iure”, 4 La Ley: Revista Jurídica Española de Doctrina, Jurisprudencia y Bibliografía(2009),pp. I440-I45O; C. Márquez Carrasco \& M. Martín Martínez, "El principio de jurisdicción universal en el ordenamiento jurídico español: pasado, presente y futuro", 40 Anuario Mexicano de Derecho Internacional (2009), pp. 25I-303; pp. 292 y ss.; A. Pigrau Solé, La jurisdicción universal y su aplicación en España: la persecución del genocidio, los crímenes de guerra y los crímenes contra la bumanidad por los tribunales nacionales (Oficina de Promoción de la Paz y de los Derechos Humanos - Generalitat de Catalunya, Barcelona, 2009); A. Remiro Brotóns, A., "Crímenes internacionales, jueces estatales", I34 Política Exterior (2010), pp. 59-68; A. Sánchez Legido, "Diez años de Derecho internacional penal", Los Derechos Humanos frente a la impunidad. Cursos de Derechos Humanos de Donostia-San Sebastián. Volumen X (2009), Servicio Editorial de la Universidad del País Vasco, pp. $269-322$. 
legislation on universal criminal jurisdiction is now even further away from what a proper regulation on that topic should be. As a result of this, the statement made in the Preamble ("Exposición de Motivos") of the 2014 Act is not true. Moreover, neither does it seem to have been drafted with transparency and honesty because it conceals the true purpose of the reform and introduces elements that are erroneous and incomplete (for example, it only makes reference to the principle of territorial jurisdiction - "Spanish territorial limits" - as the sole basis for Spanish jurisdiction in cases where there is no international treaty), as well as contradictory (arguing that an extension of national jurisdiction beyond the state's own borders involves a penetration into the realm of sovereignty of another state, while simultaneously granting the Spanish Supreme Court power to determine whether another State is really willing or not to exercise its jurisdiction in a given case, simply by examining the possible existence of a number of circumstances).

\section{WAS THE 2OI4 REFORM ACT DESIRABLE OR INEVITABLE ON NON LEGAL GROUNDS?}

Although the reform can be explained on the basis of non-legal reasons, it cannot be considered as desirable or inevitable, even if these are the only ones used. Certainly, the reasons behind the 2014 Act are connected with the profound interpenetration of law and politics in international relations. The international legal order is the legal system that is most heavily influenced by politics. Hence, this influential position is often referred to as realpolitik, in German, to highlight the fact that countries' situations and their needs, rather than convictions or principles, are usually a stronger basis for taking decisions at international level. This explains why the Spanish reforms of 2009 and 2014 were both motivated by the discomfort generated above all in Israel, China and USA as a result of various criminal complaints filed before Spain's Audiencia Nacional. But more specifically, on the one hand, the introduction of the 2009 Reform Act was hastened by the visit of an Israeli delegation to Spain earlier that year, which included amongst its members Tzipi Livni, then Minister of Foreign Affairs. This Israeli delegation expressed its discontent in the Spanish MFA regarding the criminal complaint filed against seven Israeli officials, including members of the Israeli Armed Forces and the former Defense minister as a result of the deaths of fourteen Palestinian civilians in the Gaza Strip in 2002. International law experts (and also analysts from other fields of law) highlighted at the time the fact that the reform was driven more by the Ministry of Foreign Affairs than by the Ministry of Justice. Similarly, the 2014 Reform Act was a response to the diplomatic crisis generated by the reopening of the case against $\mathrm{Hu}$ Jinta of or genocide in Tibet. The Chinese authorities' reaction was so angry that a number of experts predicted a new legislative reform in order to restrict the content of universal jurisdiction in Spain even further. In the case of China, besides its political pressure (logically very intense coming from a state of such magnitude), economic factors were also extremely important, for financial as well as commercial reasons due to the Asian giant's position as the second largest holder 
of Spain's national debt, with $20 \%$ of the total amount ${ }^{3}$. This scenario was particularly acute in view of the sovereign debt crisis then affecting Spain, along with some other Eurozone countries.

The influence of political factors in solving international issues which should be managed simply or primarily through purely legal criteria is a well known fact. It may be recalled, in this regard, that Donald Rumsfeld, former US Secretary of Defence, had publicly threatened Belgium with a possible withdrawal of NATO headquarters from Brussels. This threat seemed to be related with the subsequent abandonment of universal jurisdiction by this country, at least in the open terms in which it had initially been conceived ${ }^{4}$. The truth is that the massive leak of secret documents relating to these and other political issues, from 2010 onwards, through the not-for-profit media organisation Wikileaks, disclosed many specific aspects of such pressures, particularly with details on how intense they can be and how difficult they can be to resist.

Universal justice is an area where it is possible to perceive a rupture of the principle of sovereign equality beyond the legal space, which is also part of realpolitik. A crucial factor in this regard is what States are affected in reality by the opening of criminal proceedings. In fact, States with a legislative framework providing universal jurisdiction only react against its practical implications when certain countries, i.e., powerful and / or allies States are negatively affected, but it is simply tolerated without any other consequences when it impinges on any other country. Thus, nothing happened when universal criminal jurisdiction was applied to Rwandan citizens by French and Belgian Courts; or when Bosnian nationals were judged by German Tribunals; or Afghans by British oness.

Taking this into account, it must be recognized that a reform with such a restrictive scope regarding universal jurisdiction as that carried out through the 2014 Act can never be justified from a legal point of view, especially because it infringes rules of international law (regardless of the possible violation of domestic norms as well, including those of a constitutional nature). At the same time, the visibility and weight of non-legal reasons, (already referred to above, in particular, political and economic ones) help us to understand, naturally enough, the delicate position in which the Spanish political authorities seemed to have become trapped. Nonetheless, such reasons can never justify the content of this legislative reform. Furthermore, it should also be noted that the consideration of this context neither excludes the violation of international law nor allows for consideration of any possible circumstances precluding the wrongfulness of otherwise internationally wrongful conduct (for example, the major role of China as debt holder even within the context of the difficult economic situation in Spain was not in itself sufficient to get the Spanish 2014 Reform Act to fit the assumption of necessity, distress or force majeure or fortuitous event as possible legal circumstances to be taken into account). Our country was not shackled and could always have pursued other possibilities.

\footnotetext{
3 A. Segura, "Hacia una nueva reforma restrictiva del principio de jurisdicción universal en España", 66 Revista Española de Derecho Internacional (2014), pp. 321-324; at 323.

4 R. Brody (Human Rights Watch), text available at <http://coordinadoravictimas.blogspot.com.es/2009/o6/llantopor-la-jurisdiccion-universal.html>, accessed I5 October 2014.

5 J. Chinchón Álvarez, "Jurisdicción Universal”, Eunomia. Revista en Cultura de la Legalidad (20I4), pp. 236-247; at 244 and Redress, Manual sobre los Principios y Directrices Básicos sobre el Derecho a un Recurso y una Reparación (Redress Trust, London, 2006).
} 
Reform is incompatible with two main types of legal obligations imposed by international law on Spain, which are detailed below.

Firstly, this 2014 reform is inconsistent with the obligation of Spain (and indeed of every state) to establish its jurisdiction and prevent impunity for a series of international crimes of very serious concern: war crimes, genocide, crimes against humanity, including torture, apartheid and the forced disappearance of persons. This obligation includes or divides into different branches, crucial one being the duty to provide in advance for universal jurisdiction through criminal domestic law ${ }^{6}$.

The general obligation of establishing jurisdiction and avoiding impunity is made particularly clear and forceful in the case of war crimes through the norms of international humanitarian law (in the form of a principle of absolute universal jurisdiction expressed in articles 49, 50, I29 and I46 of Geneva Conventions I, II, III and IV and article 85.I of Protocol I), and since then it has been underpinned by the overwhelming support given by States (as is well known the ratification of the Geneva Conventions is virtually total)and subsequent reaffirmation by case law before international tribunals ${ }^{7}$. Moreover, in the case of other international crimes, proof of the existence of the same obligation can be found through various provisions contained in international conventions adopted to punish those grave offences (on genocide, torture, apartheid, forced disappearances, etc. Spain is a Party to all those conventions, with the exception of the Convention against Apartheid) and other instruments (Draft Code of Crimes against the Peace and Security of Mankind, International Law Commission, 1996), as well as the pronouncements of various Human Rights Bodies(e.g. the Committee against Torture ${ }^{8}$ ) and also of international tribunals.

It is true that international Conventions use different formulations and not all of them are equally restrictive. Thus, some are shaped to revolve around the obligation to extradite or prosecute. Although criminal jurisdiction principles and the obligation to extradite or prosecute have a partially similar aim, they cannot be held to the same because they are different things and have distinct features'. In fact, one of the main differences between them relates specifically to their customary nature. In this regard, there are still doubts regarding the possible customary scope of the obligation to extradite or prosecute in respect of most crimes against humanity, war crimes other than grave breaches, and war crimes in non-international armed conflicts ${ }^{\mathrm{I}}$. But this uncertainty should not affect

\footnotetext{
6 See also for other related obligations (such as the duty to investigate and its internal elements), ILC, Final Report of the International Law Commission, 20I4, at 9 and ICJ, Questions relating to the Obligation to Prosecute or Extradite (Belgium v. Senegal), pp. 453-454.

7 For example, ICTY, Tadic case.

8 General Comment No. 3 of the Committee against Torture. Implementation of article I4 by States parties, $\mathrm{CAT} / \mathrm{C} / \mathrm{GC} / 3$, I3 December 20I2, paragraphs $17 \mathrm{ff}$.

9 Although universal jurisdiction is a basis for the criminal competence of national courts, the obligation to extradite or prosecute is a practical mechanism to ensure the exercise of criminal jurisdiction. For other differences between them see F.J. Bariffi, "Jurisdicción Universal sobre Crímenes de Guerra: Evolución histórica y su Codificación en el Derecho de Ginebra”, I7 Revista Electrónica de Estudios Internacionales (2009); L. Benavides, "The Universal Jurisdiction Principle", Anuario Mexicano de Derecho Internacional(200I), pp. 32-36; ILC, 20I4, supra n. 6, at 8.

Io ILC, 2014, supra n. 6, at I2, 16 and I7.
} 
the principle of universal jurisdiction ${ }^{\text {II }}$. In its 2014 Final Report the ILC used the obligation to combat impunity for offences of international concern as a point of departure to work on the obligation to extradite or prosecute ${ }^{12}$.

Beyond this, it should be added that states have taken advantage of several occasions to renew their commitments through landmark instruments, of which the following deserve particular mention. First, the reference made in the Preamble to the Rome Statute for the International Criminal Court is clear in this regard, when it reminds us "that it is the duty of every State to exercise its criminal jurisdiction over those responsible for international crimes". This is a mandatory instrument for Spain (although not for states such as the US, Russia, China or Israel). Secondly, it is also necessary to stress the importance of the Updated Set of Principles for the protection and promotion of human rights through action to combat impunity, adopted within the UN framework ${ }^{13}$. And, thirdly, it seems appropriate to refer to the existence of significant UNGA resolutions based on the premise of an obligation in this regard. Emphasis can also be placed on the fact that these Resolutions have been adopted by consensus; in particular the following two: Resolution 60/147, adopted in 2005, which contains the Basic Principles and Guidelines on the Right to a Remedy and Reparation for Victims of Gross Violations of International Human Rights Law and Serious Violations of International Humanitarian Law; and Resolution 67/I, adopted in September of 2012, containing the Declaration of the High-level Meeting of the General Assembly on the Rule of Law at the National and International Levels ${ }^{14}$. Through these resolutions it is possible to perceive an inter-state agreement on the state's duty to take necessary measures to establish jurisdiction over the crimes mentioned and combat impunity. These measures of course include the state's duty to provide for universal jurisdiction in domestic law. At the same time, the adoption of these Resolutions through consensus reflects the customary character of such duties included as starting points. Furthermore, the first of those UNGA Resolutions, Resolution 60/147 (the result of almost 16 years' work), besides the approval of principles and guidelines, recommends that States take these into account to "promote

II The ILC assumed the controversial character of the obligation to extradite or prosecute in order to determine its customary nature in its Final Report. The ILC noted that some delegations to the Sixth Committee opined that there was no obligation to extradite or prosecute under customary international law, while others were of the view that this question merited further consideration by the Commission. The ILC also noted that there are important gaps in the present conventional regime governing the obligation to extradite or prosecute, in particular in relation to the crimes mentioned supra. Taking all of this into account, it placed the topic crimes against bumanity on its programme of work in 20I4, "which would include as one element of a new treaty an obligation to extradite or prosecute for those crimes"; ibid.

I2 Ibid., at 2.

I3 According to Principle 2I ("measures for strengthening the effectiveness of international legal principles concerning universal and international jurisdiction”); "States should undertake effective measures, including the adoption or amendment of internal legislation, that are necessary to enable their courts to exercise universal jurisdiction over serious crimes under international law in accordance with applicable principles of customary and treaty law (...)"; E/CN.4/Sub.2/1997/20/Rev.I, Addendum; and E/CN.4/2005/102/Add.r.

${ }_{14}$ Heads of State and Government committed themselves to "ensuring that impunity is not tolerated for genocide, war crimes, crimes against humanity and for violations of international humanitarian law and gross violations of human rights law, and that such violations are properly investigated and appropriately sanctioned, including by bringing the perpetrators of any crimes to justice, through national mechanisms or, where appropriate, regional or international mechanisms, in accordance with international law"; and for this purpose they encouraged "States to strengthen national judicial systems and institutions" (paragraph 22). 
respect thereof and bring them to the attention of members of the executive bodies of government, in particular law enforcement officials and military and security forces, legislative bodies, the judiciary, victims and their representatives, human rights defenders and lawyers, the media and the public in general" ${ }^{\text {Is. }}$. Proper training of legislators (as well as members of government and judges) seems to be crucial to enable States to fully comply with their international obligations. It would help to avoid legislation with contents such as that which we are discussing here.

Secondly, the Spanish 2014 Reform Act's content is inconsistent with obligations imposed by international law on Spain regarding the International Criminal Court. The new act introduces a provision concerning proceedings before an international tribunal established under an international treaty to which Spain is a Party, indicating that any crime will not be prosecuted in Spain in such cases. The 2014 Act conceives the ICC's jurisdiction as the preferred jurisdiction over the Spanish one. However, the legal configuration is just the opposite. The ICC was established, as expressed in Article I of its Statute, as a jurisdiction which "shall be complementary to national criminal jurisdictions". This main feature is developed across other provisions in the Statute itself ${ }^{16}$, and also in its Rules of Procedure and Evidence ${ }^{\mathrm{r}}$. Beyond any shadow of doubt, this is a fundamental issue ${ }^{\mathrm{r} 8}$.

Regardless of other possible violations of domestic Spanish law, as experts have pointed out (and on which the Spanish Constitutional Court will rule) $)^{19}$, it is clear that the infringements examined above generate an internationally wrongful act, as we have intimated. Amnesty International has also stressed this in its Report on the Spanish reform, referring also to the implications that this finding should have for the various state agencies: judges and prosecutors should apply international rules requiring Spain to resort to universal criminal jurisdiction (established in international treaties and customary norms which are compulsory for Spain) to punish perpetrators of such serious crimes; the government should stop obstructing pending criminal complaints and, together with Parliament, each within its mandate, promote a new Act fully respectful with Spain's international obligations ${ }^{20}$.

\section{WHAT APPRECIATION SHOULD SUCH A RESTRICTIVE LEGISLATIVE REFORM DESERVE ON GROUNDS OF PRACTICAL CONVENIENCE OR POLITICAL OPPORTUNITY?}

Crimes that enable or require the exercise of universal jurisdiction are usually committed in a social and political environment which is inextricably complex and usually prevents impartial judicial action, at least in the country where the offences were committed or in the State of the victims' nationality.

\section{Paragraph 2.}

6 Art. I7, on issues of admissibility.

7 See rule 162, regarding "exercise of jurisdiction" by the ICC.

I8 As a result, the 2014 reform has been criticised by experts in this regard; for further grounds for criticism see A. Martínez Guerra, "La reforma de la 'molesta' jurisdicción universal y sus primeras consecuencias", 7 Eunomia. Revista en Cultura de la Legalidad, (2014), pp. II7-I42; pp. I28 ff.

is Regarding the principle of equality, of the separation of powers and of access to effective judicial protection or to effective remedy.

20 Amnesty International, Análisis de Amnistía Internacional sobre la reforma de la jurisdicción universal en España tras la aprobación de la LO I/20I4(Amnistía Internacional, Madrid, 20I4), at 28; text available at <https://www.es.amnesty.org/uploads/media/Analisis_AI_reforma_Jurisdiccion_Universal_FIN_or.pdf>,accessed I5 October 2014 . 
These circumstances also usually prevent the principle of universal jurisdiction from being exercised successfully (there are too many difficulties to overcome in addition to the usual reticence of States, problems of evidence, etc. ${ }^{2 I}$. But when the principle of universal jurisdiction is triggered, at least, the offenders' right to free movement is limited or the State that protects them can be publicly shamed. By limiting universal jurisdiction (and also by removing the popular action to activate it, as the 2014 Act has done), Spain has created a new obstacle in the fight against impunity.

As has already been mentioned, the 2014 Spanish Act warrants sharp criticism from a legal perspective. In this sense, I agree with the criticisms that have already been levelled against it, which are highly illustrative in this regard. It has been said that the reform has "distorted"22 or "dynamited" the principle of universal criminal jurisdiction. Indeed, this reform has misinterpreted and misrepresented the contents of Spain's international obligations, introduced enormous confusion (reflecting a bad legislative technique and including serious mistakes), breached rules of international law and erased the distinctive characteristics of the principle of universal jurisdiction. At the same time, from a practical point of view, this new normative framework means that this new obstacle in the fight against impunity is not only inconvenient (being almost impossible to overcome) but also illegal.

Given all the above, after the so-called honey moon decade of international criminal law has now come to an end $^{24}$, it seems appropriate to wonder whether this Spanish legislative reform could help to erode the existing consensus amongst the international community in favour of the principle of universal criminal jurisdiction. During that golden decade the principle of universal jurisdiction had been expanded in domestic areas and the best versions in its formulation had been reached ${ }^{25}$. But at the end of that decade, a regressive trend began to appear in comparative law ${ }^{26}$.

Would it thus be possible to say, selecting arguments of political realism, that this retrograde step could also predict a reversal of the principle of universal criminal jurisdiction in international law? In order to make a proper assessment it is worth noting that backtracking in comparative law does not seem to anything to do with a possible change in States' legal convictions, but only with the discomfort that States sometimes feel, when the practical application of the principle affects certain other States. State resistance to universal criminal jurisdiction occurs when discomfort or pressure is felt in both political or (as is often the case) economic terms. But what really matters is that the State's opinio iuris remains unchanged, a fact that is becoming increasingly clear. All the indicators shown in this comment can be useful to test this assessment. Consequently, this discomfort experienced by many states, will certainly not allow the principle to expand any further (at least in the short term) across the international legal order, but it must be stressed that those same indicators

\footnotetext{
था See J. Nieva-Fenoll, "El principio de justicia universal: una solución deficiente para la evitación de hechos repugnantes”, 65 Revista Española de Derecho Internacional (2013), pp. I3I-I49; especially, pp. I36 ff.

${ }_{22}$ Ibid., at $\mathrm{II}$.

23 Martínez Guerra, supra n. I8, at iI8.

24 D. Luband, "After the Honeymoon: Reflections on the Current State of International Criminal Justice", II Journal of International Criminal Justice (2013), pp. 505-515; Chinchón, supra n. 5, at 237.

25 See Sánchez Legido, supra n. I, Parts Three and Four and also at 385.

${ }^{26}$ See R. Alija Fernández, R., "El alcance de la jurisdicción universal a la luz de la evolución de la práctica estatal”, II2 Tiempo de Paz(2014), pp. I3-I8.
} 
reflect the existence of elements able to prevent universal jurisdiction from taking a backwards step at the international legal level as well. It should be emphasized in this regard that universal criminal jurisdiction is deeply connected with many other issues where inexorable progress is still on going, including globalization, the erosion of state sovereignty, the proliferation of international jurisdictions, human rights protection and the fight against impunity.

In line with the foregoing, we can end this comment by concluding that the Spanish reform does not in itself have the capacity to adversely affect the status of universal criminal jurisdiction in international law. It should be noted that explanations contained in the "Exposición de Motivos" of the 2014 Spanish Act (a sort of preamble or explanatory introduction to it - as has already been expressed-, and therefore, always relevant for the purposes of measuring a country's opinion juris) will be a key factor in this regard. This 'preamble' assumes, as we have seen, that Spain has international legal obligations with regard to universal jurisdiction (even though the assumption's content is wrongly made and hence the sense of the reform is mistaken). But what is more relevant is that this explanatory preamble has done everything except what could really jeopardize the threshold reached regarding the necessity of universal jurisdiction in the international community. That would have been the case if it had challenged its validity or current effect. In this sense, it must be stressed that the 2014 Act has not challenged either the usefulness or the suitability of the principle of universal justice. Universal jurisdiction remains in full force at international level. There is therefore still room for hope, and above all for critical action to be taken by civil society. It is crucial to make up the time that is unfortunately currently being lost in this area. 